\title{
MISCELLANEA
}

\author{
ŁUKASZ MARZEC
}

Uniwersytet Jagielloński

\section{CZY PRAWO ANGIELSKIE TO TYLKO COMMON LAW?}

Na marginesie artykułu Rafała Mańko Sqdowe stosowanie Corpus Iuris Civilis w Afryce Potudniowej w świetle wybranych orzeczeń, «Zeszyty Prawnicze [UKSW]» 4.1 (2004), s. 162-178

Interesujący artykuł Rafała Mańko utwierdza w przekonaniu, iż prawo rzymskie z powodzeniem można jednak stosować współcześnie. Jakże ciepło dla romanisty brzmią wypowiedziane w 1988 r. słowa Prezesa Sądu Najwyższego Zimbabwe: „Nie ma wątpliwości, że Edykt Pretorski (...) stanowi część prawa Zimbabwe i Południowej Afryki"'. Dzisiejszego prawnika musi również szczególnie zainteresować udane połączenie systemu precedensu z obowiązującym walorem prawa rzymskiego. Jak bowiem pokazują dzieje historii prawa, w Anglii - ojczyźnie nowożytnego prawa precedensowego zasięg i stopień recepcji prawa rzymskiego był w porównaniu do kontynentu zdecydowanie ograniczony².

' R. MańKo, Sadowe stosowanie 'Corpus Iuris Civilis' w Afryce Potudniowej w świetle wybranych orzeczeń, «Zeszyty Prawnicze [UKSW]» 4.1 (2004), s. 151.

${ }^{2}$ Historyczny zakres i stopień recepcji prawa rzymskiego w Anglii stanowi obecnie przedmiot zainteresowania wielu autorów komparatywistów. Tematykę tę 
Uważna lektura przytoczonego przez autora uzasadnienia wyroku Przylądkowego Wydziału Prowincjonalnego w sprawie Janse van Rensburg v. Grieve Trust ${ }^{3}$ skłania do pewnych przemyśleń na temat recepcji zasad aequitas $\mathrm{w}$ angielskim systemie prawnym, a szczególnie rozumienia zakresów pojęć „prawo angielskie” i „common law”. Sędzia-sprawozdawca Van Zyl referując sprawę posłużył się między innymi taką argumentacją, przytoczoną przez autora artykułu: „Nasze prawo nie uznaje prawa słuszności tak jak prawo angielskie, chociaż ograniczona recepcja słusznościowych zasad prawa rzymskiego $\mathrm{w}$ angielskim common law miała miejsce począwszy od wczesnego średniowiecza"4. Pomijając całkowicie kwestię obecności zasad słuszności w omawianym przez autora systemie prawnym $^{5}$, należy rozważyć zagadnienie relacji prawa angielskiego do common law, a także zasygnalizować problem recepcji tamże zasad rzymskiej aequitas.

Utożsamianie prawa angielskiego z common law tak jak uczynił to sędzia Van Zyl jest zjawiskiem bardzo rozpowszechnionym. Tymczasem, szczególnie w powołanej w orzeczeniu dalekiej perspektywie historycznej, common law stanowiło tylko jeden z elementów składowych systemu „prawa angielskiego”, podobnie jak Anglia jest tylko jedną z kilku geograficznych części Brytanii. Zagadnienie to pozostaje zresztą $\mathrm{w}$ pewnej relacji do akcentowanego ostatnio przez N. Daviesa problemu pojmowania historii Wysp Brytyjskich jako tożsamej jedynie z historią Anglii, przy jednocze-

podejmowali ostatnio w Europie P. Stein, R. Zimmermann, W. Knütel czy M. Reimann, a w USA M. Hoeflich, R. Helmholz czy A. Watson. Por. też K. ZweigerT, H. KöTZ, Einführung in die Rechtsvergleichung, Tübingen 1996, a z najnowszych pozycji pracę R. Zimmermanna, Roman Law, Contemporary Law, European Law. The Civilian Tradition Today, Oxford 2001. Wykaz literatury tematu znaleźć można u M. ReImanna, Who is afraid of the Civil Law? Kontinentaleuropäisches Recht und Common Law im Spiegel der englischen Literatur seit 1500, «Zeitschrift für Neuere Rechtsgeschichte» 21 (1999), s. 357-381.

${ }^{3}$ R. MAŃKO, op. cit., s. 157-165.

+ Cyt. za R. MańKO, op. cit., s. 162.

${ }^{5} \mathrm{Na}$ ten temat por. literaturę powołaną w artykule R. MAŃKO. 
snym pomijaniu udziału pozostałych jej elementów, jak Szkocja, Walia lub Irlandia 6 .

Common law, kształtujące się w Anglii od początku panowania dynastii normańskiej aż po koniec XIX w obejmowało w zakresie prawa prywatnego jedynie wycinek ogólu regulowanych kwestii. Pozostałymi elementami systemu - całkowicie niezależnymi, a wręcz konkurencyjnymi - były między innymi: equity law administrowane przez Sąd Kanclerski, morskie i częściowo powszechne prawo handlowe pozostające w jurysdykcji Sądu Admiralicji, sądy kościelne z Court of the Arches na czele, rozpatrujące sprawy z zakresu prawa rodzinnego i częściowo spadkowego, sąd wojskowy Court of the Constable and the Marshall, prawa dotyczące społeczności akademickich pozostające w administracji sądów uniwersyteckich. Należy tu wymienić również instytucje sprawujące rozmaitą i zmienną przedmiotowo jurysdykcję, jak Sąd Izby Gwiaździstej (Star Chamber), Tajną Radę (Privy Council) czy powiązany z Sądem Kanclerskim Urząd Próśb (Court of Request).

Użyte powyżej określenie „konkurencyjne” nie jest przy tym przesadzone. Holdsworth nie zawahał się przed terminem „rywalizacja". Spojrzenie na długą historię niełatwych relacji pomiędzy sądami common law a ich rywalami jak Court of Admiralty ${ }^{9}$ czy Court of Chancery pozwala uznać powyższe określenia za zbyt łagodne. Właściwie byłoby mówić wręcz o agresji, z jaką sędziowie „westminsterscy" - czterech sądów common law - zwalczali zawodową konkurencję. Dzieje instytucji sądowych działających poza nawiasem common law są równie długie jak jego samego. Pierwsze relacje z działań obu najpoważniejszych konkurentów w zakresie jurys-

- N. DAviES, Smok wawelski nad Tamiza. Eseje, polemiki, wykłady, Kraków, 2001, s. 177-196; TENżE, Wyspy, Kraków 2003, s. 19-42.

' Por. np. H. KuPISZEwSKi, Prawo rzymskie a wspótczesność, Warszawa 1988, s. 122.

${ }^{8}$ Por. tytuł księgi IV historii prawa angielskiego W. HoldsworthA, A History of English Law, IV: Common law and its Rivals, London 1973.

${ }^{9} \mathrm{Na}$ temat tego sądu por. L. MARZEC, Kilka uwag o sądownictwie Admiralicji w Anglii, «Zeszyty Prawnicze [UKSW]» 4.1 (2004), s. 75-89. 
dykcji pochodzą ze średniowiecza. Tryb działania obu tych sądów był odmienny na tyle, że do ich zawodowej obsługi (sędziowskiej i adwokackiej) potrzebni byli prawnicy $z$ uniwersyteckim stopniem z prawa rzymskiego, w przeciwieństwie do kształconych wyłącznie korporacyjnie common lawyers. Stanowili oni niewielką, ale bardzo sprawnie zorganizowaną i wpływową grupę zawodową ${ }^{10}$ skupioną w elitarnej organizacji Doctors' Commons. Sąd Admiralicji nie opierał swojego orzecznictwa na precedensach, nie istniała nawet praktyka spisywania i wydawania reports z działalności, jak czyniono to w sądach common law. Mniej więcej na przełomie panowania Tudorów i Stuartów owe konkurencyjne instytucje bardzo poważnie „zachwiały systemem precedensu”"11.

Utożsamianie całego prawa angielskiego tylko z common law skutkuje zatem pominięciem bardzo istotnych elementów składających się w równorzędny sposób na historyczny obraz systemu prawa Wielkiej Brytanii.

W kwestii recepcji „słusznościowych zasad prawa rzymskiego” należałoby się najpierw pokusić o ich bliższe określenie. Istnienie równoległego systemu norm - mającego na celu tak jak w Rzymie adiuvare, corrigere et supplere podstawowego prawa służyło realizacji idei królewskiej sprawiedliwości poprzez stosowanie reguł słuszności. Będzie to szereg zasad wytworzonych przez wielowiekowe orzecznictwo Chancery, których jednak nie można uznać za przejęte wprost z prawa rzymskiego, choć niektóre cechuje uderzające podobieństwo. Chodzi tu raczej o recepcję idei sprawiedliwości przez słuszność i rozsądek, która przyświecała pretorskiemu ius honorarium. Powszechnie wymienia się tu tzw. rules of equity, jak "He who comes into equity must come with clean hands"12, "He who will have equity must do it", "no one shall be permitted to profit from his own fraud, or to ta-

\footnotetext{
${ }^{10}$ Por. Ł. Marzec, Civil lawyers w Anglii Tudorów i pierwszych Stuartów. Ze studiów nad prawem rzymskim w Anglii, «CPH» 55.2 (2003), s. 213-230.

${ }^{11}$ P. Koschaker, Europa und das Römisches Recht, München 1958, s. 112.

${ }^{12}$ Por. np. warunki zastosowania rzymskiej actio doli (D. 4,3,36).
} 
ke advantage of his own wrong" ${ }^{13}$ oraz szereg innych ${ }^{14}$. Zagadnienia te omawia zresztą H. Kupiszewski w znanej pracy „Prawo rzymskie a współczesność”. Doktryna daleka jest również od uznania bezpośredniego rzymskiego pochodzenia koncepcji dwóch równoległych gałęzi prawa, chociaż wyprowadza się tu szereg daleko idących analogii. Orzecznictwo Chancery stanowiące remedium na brak elastyczności common law wiele zawdzięcza prawu rzymskiemu, żeby wspomnieć choćby o truście ${ }^{15}$ (fidekomis) czy pożyczce hipotecznej (equity of redemption - zakaz klauzuli przepadku lex commissoria).

Pozostaje zatem kwestia formalnego połączenia obu gałęzi prawa angielskiego, common law i equity law w następstwie Judicature Act w drugiej połowie XIX w. Nie nastąpiło jednak zlanie obu mas w jeden system, a jedynie powołanie nowej instytucji sądowej (High Court of Justice) administrującej zarówno w zakresie common law jak i equity, choć w wydzielonych izbach ${ }^{16}$. Jakkolwiek w następstwie tego aktu Sąd Kanclerski przestał istnieć, do życia powołano z kolei Wydział Kanclerski w High Court of Justice, kontynuujący pracę zniesionego sądu. Unifikacja miała zatem charakter formalny, jakkolwiek w jej następstwie to właśnie common law doznało wpływów „słusznościowych”"17, a nie odwrotnie. Jedynie na marginesie warto nadmienić, iż samo common law nie było wcale herme-

\footnotetext{
${ }^{13}$ Por. D. 50,17,134,1: Nemo ex suo delicto meliorem suam condicionem facere potest.

${ }^{14}$ Por. np. H. KupiszewsKi, op. cit., s. 122 i n.

${ }^{15}$ Por. P. Stein, Roman Law in European History, Cambridge 1999, s. 88: „In working out the duties of trustees in regard to their management of trust property, the chancellors could find help in civil law discussions of the duties of tutors responsible for administering the property of wards under the age of puberty. Equity was therefore more open to civil law influence than the traditional common law".

${ }^{16}$ Por. np. Oxford Dictionary of Law, 1994, s. v. equity: „(...) Under the Judicature Acts 1873-75, with the establishment of the High Court of Justice to administer both common law and equity, the Court of Chancery was abolished (though much of its work is still carried out by the Chancery Division)".
}

${ }^{17}$ H. KuPISZEWSKI, op. cit., s. 122-123. 
tycznie zamknięte na wpływy $\mathrm{z}$ kontynentu ${ }^{18}$, chociaż często decydującą rolę odgrywała postawa i charyzma konkretnego prawnika. Za przykład mogą posłużyć zarówno sir Edward Coke (1551-1634), jeden z przywódców Parlamentu w sporze z Karolem Stuartem, broniący niezależności common law jako najwyższej racji stanu, jak i sir William Murray, lord Mansfield (1705-1793), który przewodnicząc czołowemu sądowi common law - King `s Bench, doprowadził do ukształtowania angielskiego prawa handlowego w dużej mierze w myśl zasad prawa rzymskiego.

Można zatem stwierdzić, iż niektóre zasady rzymskiej aequitas, które przybrały w Anglii formę law of equity, stanowiły istotny element tamtejszej kultury prawnej. Z pewnością jednak ich częściowa recepcja dochodziła do skutku poprzez działalność Sądu Kanclerskiego którego sędziowie chętnie korzystali z dorobku prawa rzymskiego, a nie czterech sądów „westminsterskich”, ostoi common law. Pogląd sędziego Van Zyla o średniowiecznych korzeniach zasad słuszności w common law jest zatem - choć co do zasady słuszny - nieściśle wyrażony. Common law, choć dzisiaj stało się symbolem dawnego Imperium, było jednak tylko częścią wielkiego dziedzictwa prawnego Brytyjczyków.

${ }^{18}$ Por. np. T. ScRUtTon, The Influence of the Roman Law on The Law of England, Cambridge 1885, W. BuCKLAND, A. MCNAIR, Roman law and common law. A comparison in outline, Cambridge 1965, D. IBBETSON, $A$ historical introduction to the law of obligations, Oxford 1999, TENżE, Common law and ius commune, London 2001, R. Helmholz, The 'ius commune' in England: four studies, Oxford 2001. 